УДК 621.86

СВ.3. Гудь, к.т.н., В.М. Клендій, к.т.н., І.М. Шуст

Тернопільський національний технічний університет імені Івана Пулюя

\title{
РЕЗУЛЬТАТИ ДОСЛІДЖЕНЬ ТЕЛЕСКОПІЧНОГО ГВИНТОВОГО ТРАНСПОРТЕРА
}

\begin{abstract}
Розроблено експериментальне обладнання з допомогою якого проведено дослідження телескопічного гвинтового транспортера згідно розроблених методик. $B$ результаті проведених досліджень було встановлено, щз найбільшою проблемою в телескопічних гвинтових транспортерах $\epsilon$ збереження однакового зазору між кожухом та спіраллю в різних секиіях телескопа, що значно впливає на час викочування та закочування рухомої в осьовому напрямку частини шнека на нерухому. Також встановлено, щчо продуктивність перевантаження сільськогосподарських вантажів телескопічним гвинтовим транспортером не відрізняється від продуктивності перевантаження ичих матеріалів традиційними гвинтовими конвеєрами.

ЕКСПЕРИМЕНТАЛЬНЕ ДОСЛІДЖЕННЯ, ТЕЛЕСКОПІЧНИЙ ТРАНСПОРТЕР, ГВИНТОВИЙ КОНВЕСР, ТРАНСПОРТУВАННЯ, МЕХАНІЗМ, МАШИНА, МАТЕРІАЛ
\end{abstract}


Постановка проблеми. Гвинтові транспортери широко використовуються у сільському господарстві як самостійні механізми, так і у складі різноманітних механічних систем. Часто їх використовують у якості елементів сільськогосподарських машин при збиранні врожаю для перевантаження різноманітних вантажів в польових умовах. Гвинтові транспортери у складі універсальних агрегатів для завантаження сівалок, бункерах-перевантажувачах та зернозбиральних комбайнах виконуються, як правило, складними i передбачають розкладення-складення з допомогою гідро- чи пнемоустаткування, що робить їх конструкції надто складними i дорогими. Відповідно $з$ метою удосконалення конструкцій та для забезпечення необхідної траєкторії перевантаження матеріалів гвинтовими транспортерами актуальним $\epsilon$ питання пошуку прогресивних аналогів, до яких належать телескопічні гвинтові транспортери.

Аналіз останніх досліджень і публікацій. Розробленню конструкцій стендового обладнання для дослідження різноманітних гвинтових транспортерів присвячені праці Турпаєва А.I. [1], Сисоліна В.П. [2], Григорьєва А.М. [3], Гевка Б.М. [4], Рогатинського Р.М. [5], Гевка І.Б. [7], та інших. Проте цілий ряд питань, які стосуються дослідження їх характеристик, таких як продуктивності та питомих енерговитрат в залежності від різних параметрів, потребують свого подальшого вивчення особливо для новостворених конструктивних рішень.

Мета дослідження. Метою роботи $\epsilon$ експериментальне дослідження характеристик телескопічного гвинтового транспортера.

Результати дослідження. В значній кількості універсальних агрегатів-перевантажувачів сільськогосподарських вантажів для досягнення необхідної відстані перевантаження шнековий конвеєр виконується складним i розкладаєтьсяскладається 3 допомогою гідро- чи пнемоустаткування, що робить його конструкцію надто складною. Відповідно використання принципу телескопу в шнекових транспортерах може віднайти широке застосування в різноманітних конструкціях сільськогосподарської техніки.

Для проведення експериментальних досліджень телескопічних гвинтових транспортерів на основі проведеного патентного пошуку та аналізу наукових літературних джерел [6] i проведеного синтезу [8] було розроблено і запатентовано ряд конструкцій гвинтових конвеєрів з обертовими кожухами, на базі 
яких спроектовано i виготовлено стенд для дослідження транспортування сипких вантажів (рис. 1 - рис. 3 ).

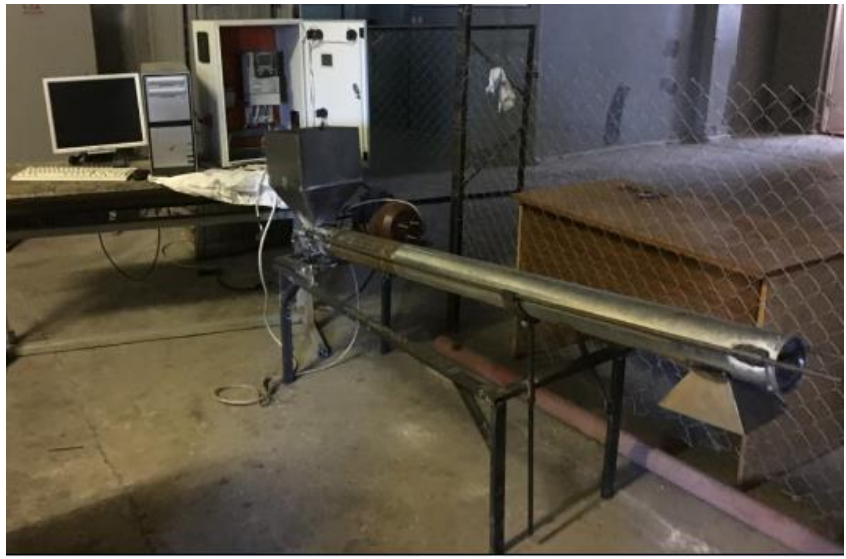

a)

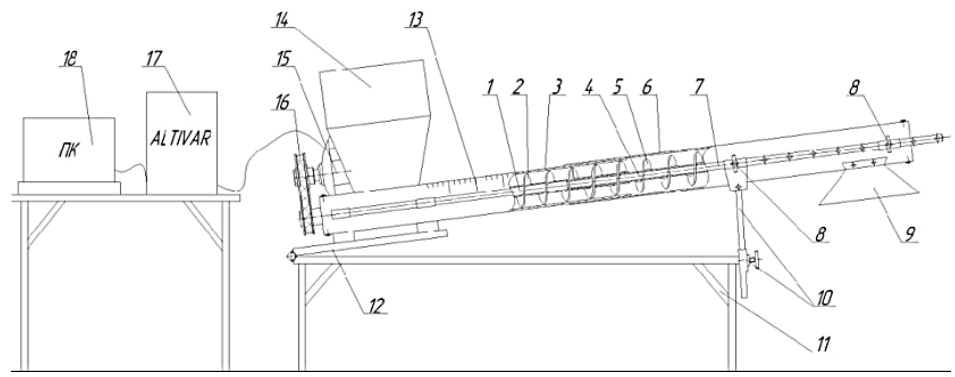

б)

Рис. 1 - Стенд для дослідження характеристик телескопічних гвинтових транспортерів: а) загальний вигляд; б) конструктивна схема; 1 - нерухома в осьовому напрямку секція гвинта; 2 - шнек нерухомої в осьовому напрямку секції гвинта; 3 - нерухома в осьовому напрямку частина кожуха; 4 - рухома в осьовому напрямку секція гвинта; 5 - шнек рухомої в осьовому напрямку секції гвинта; 6 - рухома в осьовому напрямку частина кожуха; 7 направляючі; 8 - фіксатори направляючих; 9 - вивантажувальний патрубок; 10 - опора регулювання висоти подачі матеріалу; 11 рама; 12 - рухомий стіл; 13 - шкала перекривання шнеків; 14 бункер; 15 - електропривід транспортера; 16 - пасова передача; 17 перетворювач частоти обертання приводу; 18 - персональний комп'ютер 
Стенд для дослідження характеристик телескопічних гвинтових транспортерів (рис. 1 - рис. 3) виконано у вигляді рами 11, на якій закріплено з можливістю колового провертання рухомий стіл 12 і з можливістю переміщення у вертикальному напрямку опору регулювання висоти подачі матеріалу 10. На рухомому столі 12 жорстко встановлено електропривід транспортера 15 та нерухому в осьовому напрямку частину кожуха 3, в якій встановлено 3 можливістю колового провертання нерухому в осьовому напрямку секція гвинта 1 із шнеком 2. В одній частині кожуха 3 у підшипниковій опорі розташовується секція гвинта 1 (на рис. 2 у лівій) $з$ шківом пасової передачі 16, а інша частина кожуха входить в зачеплення з рухомою в осьовому напрямку частиною кожуха 6 . Аналогічно входять в зачеплення нерухома 1 i рухома в осьовому напрямку 4 секції гвинта та шнеки нерухомої 2 та рухомої в осьовому напрямку 5 секцій гвинта. Причому зовнішній діаметр шнеків $є$ рівним, а внутрішній діаметр шнека рухомої в осьовому напрямку секції гвинта 5 є більшим, як у шнека 2, для можливого провертання по секції 1. Шнек 2 жорстко беззазорно по всій його довжині закріплено до секції 1 (труби), а шнек 5 жорстко закріплено до секції 4 лише у крайній правій частині, що знаходиться в підшипниковій опорі у правому кінці кожуха 6. Секція 4 виконана у вигляді труби, яка має зовнішній діаметр дещо меншим за внутрішній діаметр труби секції 1, і своїм лівим кінцем входить в зачеплення 3 можливістю осьового і колового зміщення в трубу секції 1. Відповідно шнек 5 своєю лівою частиною може ковзати по трубі секції 1 вгвинчуючись чи розгвинчуючись зі шнеком 2, тим самим збільшуючи чи зменшуючи трасу перевантаження вантажів телескопічного гвинтового транспортера. По боках нерухомої 3 та рухомої 6 частин кожуха в жорстко закріплених до них опорах розташовані направляючі 7, що регулюють довжину телескопічного гвинтового транспортера 3 допомогою фіксаторів 8. У лівій частині кожуха 3 знаходиться бункер для завантаження сипкого матеріалу, а у правій частині кожуха 6 закріплено вивантажувальний патрубок 9. Електродвигун 15 через пасову передачу з'єднано з валом секції 1. На нерухомій 3 частині кожуха (рис. 3) виконано шкалу перекривання шнеків 13, 3 допомогою якої можна визначати ефективність процесу перевантаження матеріалу при відповідному розсуванні транспортера. Кожух 6 розташовано на опорі регулювання висоти подачі матеріалу 10 з можливістю осьового переміщення. До електроприводу транспортера 15 під’єднано перетворювач частоти обертання приводу 17 (Altivar 71), який керується 3 персонального 
комп'ютера (ПК) 18. Ним через ПК здійснюється керування роботою двигуна і гвинтового конвеєра загалом, і при цьому $\epsilon$ можливість плавного нарощування та зменшення частоти обертання шнека в широких межах, що дозволяють виконувати дослідження згідно розробленої методики проведення експериментів.

У вихідному положенні стенд для дослідження характеристик телескопічних гвинтових транспортерів знаходиться у згвинченому стані (максимально загвинчені шнеки 2 і 5). При проведенні експериментальних досліджень шнек 5 розгвинчують зі шнека 2 на потрібну відстань, тим самим збільшуючи трасу перевантаження вантажів телескопічного гвинтового транспортера. При забезпеченні необхідної відстані 3 допомогою фіксаторів 8 фіксуються направляючі 7 , які регулюють довжину телескопічного гвинтового транспортера. Також за допомогою опори регулювання висоти подачі матеріалу 10 , яку закріплено на рамі 11 , регулюється нахил рухомого стола 12 i, відповідно, робочого органу транспортера до горизонту.

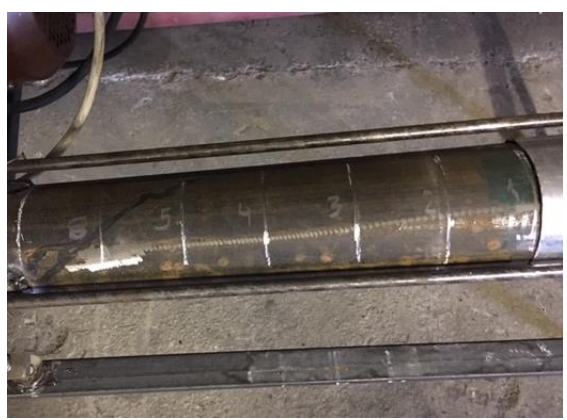

Рис. 2 - Шкала перекривання шнеків стенду для дослідження характеристик телескопічних гвинтових транспортерів

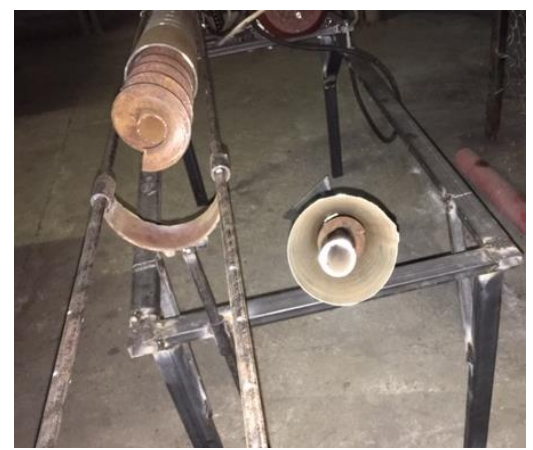

Рис. 3 - Стенд для дослідження телескопічних гвинтових транспортерів в розібраному стані

Виконуючи дослідження завантажують бункер 14 сипким матеріалом, який 3 нього потрапляе в кожух 3 на шнек 2, яким здійснюється його транспортування до кожуха 6 на шнек 5, і далі сипкий матеріал через вивантажувальний патрубок 9 потрапляє до мірного посуду. Обертовий рух шнек 2 отримує через пасову передачу від електроприводу 15 , керування якими здійснюється 3 ПК з фіксацією усіх необхідних даних у табличному чи графічному вигляді згідно розробленої методики проведення 
експериментальних досліджень. Зі шнека 2 обертовий рух передається на шнек 5 за рахунок тертя, що виникає між стінками шнеків, що й дозволяє проводити процес перевантаження сипкого матеріалу. При цьому продуктивність телескопічного гвинтового транспортера при різних коефіцієнтах заповнення кожуха та частотах обертання шнека визначається в напівавтоматизованому режимі. Силові характеристики можна визначати при плавному та різкому пуску, реверсуванні та моделюванні різноманітних навантажень в автоматизованому режимі за допомогою перетворювача частоти та персонального комп'ютера.

При виконанні досліджень на розробленому стенді завдяки програмі PowerSuite можна змінювати: плавно i різко частоту обертання шнека від 0 до 1400 об/хв.; кут нахилу телескопічного гвинтового конвеєра відносно горизонту від 0 до 90 градусів; забезпечувати обертання шнека в реверсному напрямі. В процесі проведення випробувань фіксація даних проводиться із наперед заданою частотою, і вони відображаються на моніторі ПК у вигляді табличних даних та графічних залежностей у процентному співвідношенні до номінальної потужності.

В дослідній установці зовнішній діаметр шнека становить 97 мм; внутрішній діаметр нерухомого патрубка - 100 мм; зовнішній - 107 мм; внутрішній діаметр рухомого патрубка - 109 мм. Рухомий патрубок виконано із оцинкованого листа, а тому він містить з'єднювальний шов і овальності та нерівності по усій довжині, що впливало на швидкість скручування і розкручування телескопічної частини гвинтового транспортера.

3 допомогою виготовленого стенду нами досліджено:

1. Процес викочування (вигвинчування) рухомої в осьовому напрямку частини шнека з нерухомої (рис. 4 - рис. 6).

2. Процес закочування (вгвинчування) рухомої в осьовому напрямку частини шнека на нерухому (рис. 7 - рис. 9).

3. Продуктивність телескопічного гвинтового конвеєра при транспортуванні кукурудзи при різній частоті обертання шнека (рис. 10).

4. Крутний момент на валу привода шнека при транспортуванні кукурудзи при різній частоті обертання шнека (рис. 11).

5. Витрати потужності приводу шнека при транспортуванні кукурудзи при різній частоті обертання шнека (рис. 12).

В результаті проведених досліджень було встановлено, що найбільшою проблемою в телескопічних гвинтових транспортерах $\epsilon$ збереження однакового зазору між кожухом та спіраллю в різних 
секціях телескопа, що значно впливає на час викочування та закочування рухомої в осьовому напрямку частини шнека на нерухому. Також встановлено, що продуктивність перевантаження сільськогосподарських вантажів телескопічним гвинтовим транспортером не відрізняється від продуктивності перевантаження цих матеріалів традиційними гвинтовими конвеєрами.

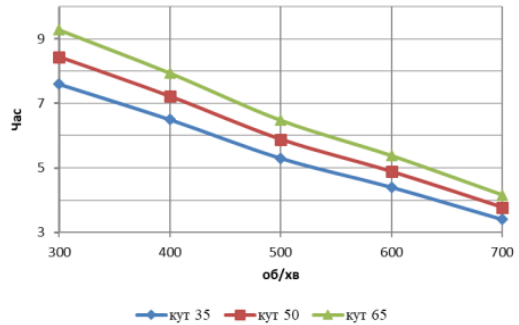

Рис. 4 - Час викочування шнека від його обертів

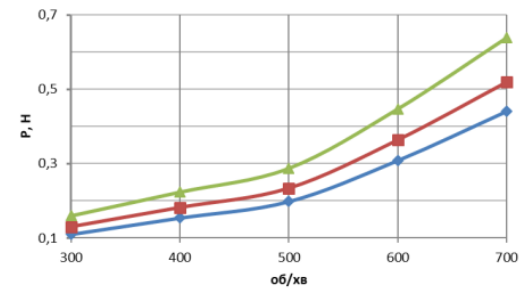

$\leadsto$-кут $35-$-кут $50 \leadsto-$ кут 65

Рис. 6-Витрати потужності при викочуванні шнека від його обертів

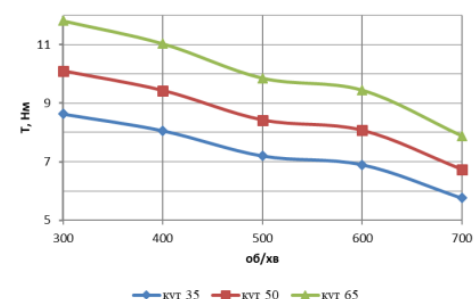

Рис. 8 - Крутний момент при закочуванні шнека від його обертів

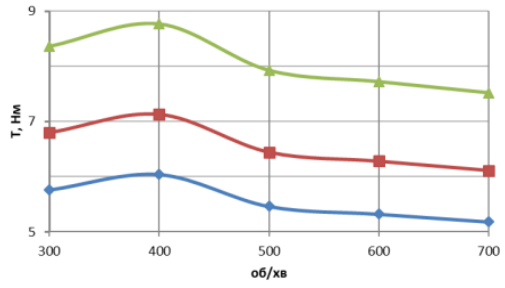

๑ே кут $35-$ -

Рис. 5 - Крутний момент при викочуванні шнека від його обертів

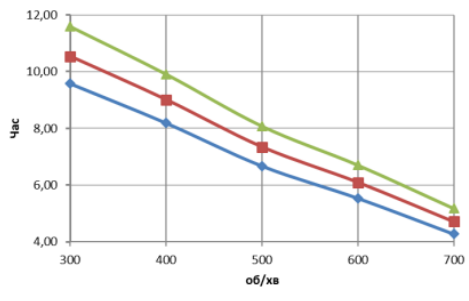

$\rightarrow$ -

Рис. 7 - Час закочування шнека від його обертів

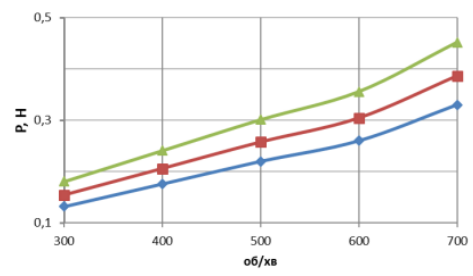

$\rightarrow$ - кyг $35 \rightarrow$-kyг $50 \multimap$ кyг 65

Рис. 9 - Витрати потужності при закочуванні шнека від його обертів 


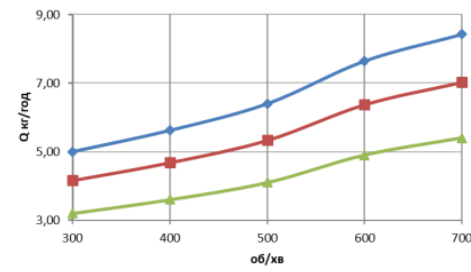

$\multimap$ кут $35-$ -

Рис. 10 - Продуктивність перевантаження кукурудзи при різній частоті обертання шнека

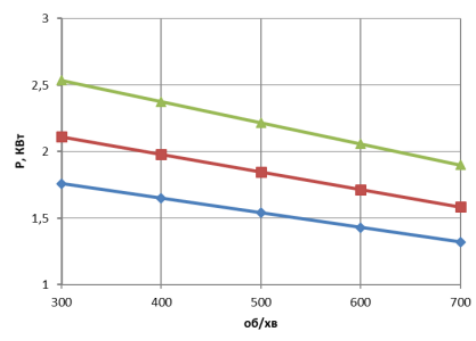

$\rightarrow$ - кyт $35-$ - кyт $50 \multimap-$ кyт 65

Рис. 12 - Витрати потужності при перевантаженні кукурудзи при різній частоті обертання шнека

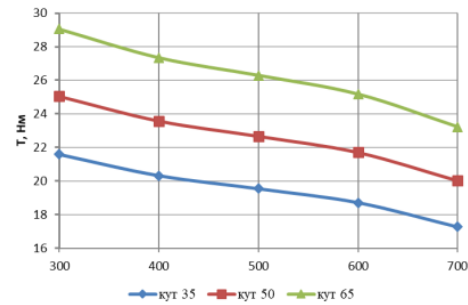

Рис. 11 - Крутний момент при перевантаженні кукурудзи при різній частоті обертання шнека

Висновоки. В результаті проведених досліджень було встановлено, що найбільшою проблемою в телескопічних гвинтових транспортерах $\epsilon$ збереження однакового зазору між кожухом та спіраллю в різних секціях телескопа, що значно впливає на час викочування та закочування рухомої в осьовому напрямку частини шнека на нерухому. Також встановлено, що продуктивність перевантаження сільськогосподарських вантажів телескопічним гвинтовим транспортером не відрізняється від продуктивності перевантаження цих матеріалів традиційними гвинтовими конвеєрами.

\section{Література}

1. Турпаев А. И. Винтовые механизмы и передачи [Текст] / А. И. Турпаев. - М. : Машиностроение, 1982. - 223с.

2. Сисолін В. П. Сільськогосподарські машини. Теоретичні основи. Конструкція і проектування [Текст] / В. П. Сисолін - К. : Урожай, 2001.-382c. 
3. Григорев А. М. Винтовые конвейеры. [Текст] / А. М. Григорев. - М. : Машиностроение, 1972. - 184c.

4. Гевко Б. М. Механізми з гвинтовими пристроями [Текст] / Б. М. Гевко, Р. М. Рогатинський. - Львів: Світ, 1993. - 208c.

5. Рогатинський Р. М. та інші Науково-прикладні основи створення гвинтових транспортно-технологічних механізмів. / Рагатинський Р. М., Гевко І. Б., Дячун А. Е., Тернопіль, 2014. $280 \mathrm{c}$.

6. Рогатинський Р.М., Гевко І.Б. Модель конструювання і вибору гвинтових конвеєрів 3 розширеними технологічними можливостями/ [Р. М. Рогатинський, І. Б. Гевко] // Вісник ТНТУ, Тернопіль, 2012, №3 (67), с.197-210.

7. Стендове обладнання для дослідження модернізованих гвинтових конвеєрів / [І. Гевко, А. Дячун, А. Мельничук та ін.] // Вісник НУВГП. - 2016. - № 3 (75). - С. 274-282.

8. Синтез телескопічних гвинтових конвеєрів [І. Гевко, В. Гудь, I. Шуст та ін.] // Вісник ХНТУСГ імені Петра Василенка. «Ресурсозберігаючі технології, матеріали та обладнання у ремонтному виробництві» - 2016. - Випуск №168, С. 85-91. 